\title{
Vigor evaluation of stored cotton seeds, including the Seed Vigor Imaging System $\left(\text { SVIS }^{\circledR}\right)^{1}$
}

\author{
Renata Oliveira Alvarenga ${ }^{2 *}$, Julio Marcos-Filho ${ }^{2}$
}

\begin{abstract}
This study aimed at evaluating efficiency of different tests to assess cotton seed vigor during storage, including the SVIS ${ }^{\circledR}$ software. Thereby, five cotton seed lots (cv. BRS 293) were stored under controlled environmental conditions of low temperature and relative humidity $\left(10{ }^{\circ} \mathrm{C} ; 30 \% \mathrm{RH}\right)$, and under non-controlled laboratory environmental conditions, for eight months. Evaluations of germination, first germination count, cool germination, accelerated aging test traditional and with saturated salt, field seedling emergence and seedling imaging automated analysis - SVIS ${ }^{\circledR}$ were performed before and after every two storage months. It was concluded that the cool germination, accelerated aging (traditional and with saturated salt), field seedling emergence and seedlings length $\left(\right.$ SVIS $\left.^{\circledR}\right)$ are adequate parameters for assessing vigor of cotton seeds during storage, and that both accelerated aging and SVIS ${ }^{\circledR}$ (vigor index and seedlings length) present enough sensitivity to identify changes on seed vigor during storage.
\end{abstract}

Index terms: Gossypium hirsutum L., physiological potential, storage.

\section{Avaliação do vigor de sementes armazenadas de algodão, incluindo a análise computadorizada de imagens $\left(\mathrm{SVIS}^{\circledR}\right)$}

\begin{abstract}
RESUMO - O presente trabalho teve como objetivo verificar a eficiência de diferentes testes na avaliação do vigor de sementes de algodão ao longo do armazenamento, incluindo o SVIS ${ }^{\circledR}$. Cinco lotes de sementes de algodão (cv BRS 293) foram armazenados em câmara fria e seca $\left(10{ }^{\circ} \mathrm{C}\right.$ e $30 \%$ UR do ar) e em ambiente natural, durante oito meses. As avaliações da germinação e do vigor (primeira contagem de germinação, germinação a baixa temperatura, envelhecimento acelerado tradicional e com solução saturada de $\mathrm{NaCl}$, emergência de plântulas em campo e análise computadorizada de imagens de plântulas - SVIS ${ }^{\circledR}$ ) foram realizadas no início e a cada dois meses de armazenamento. Concluiu-se que os testes de germinação a baixa temperatura, envelhecimento acelerado (tradicional e com solução saturada de $\mathrm{NaCl}$ ), emergência de plântulas em campo e SVIS ${ }^{\circledR}$ (comprimento de plântulas) são adequados para avaliação do vigor de sementes de algodão durante o armazenamento. Além disso, os testes de envelhecimento acelerado (tradicional e com solução saturada de $\mathrm{NaCl}$ ) e as análises SVIS ${ }^{\circledR}$ (índice de vigor e comprimento de plântulas) apresentam sensibilidade na identificação da queda do vigor das sementes durante o armazenamento.
\end{abstract}

Termos para indexação: Gossypium hirsutum L., potencial fisiológico, armazenamento.

\section{Introduction}

Among parameters used to assess the quality of a seed lot, the physiological potential is essential. It is known that the final destination of a seed is the field; and, therefore, the establishment of a suitable plant stand is a priority for producers. Thus, to ensure seedling emergence in the field it becomes essential to previously assess the seed vigor, aiming at identifying seed lots that present higher chance of adequately establishing in the field and provide the expected return (Marcos-Filho, 2005).
The assessment of seed physiological potential is usually performed through germination and vigor tests. The vigor tests are regarded as important for revealing relatively narrow variations in the different deterioration stages of the seeds of a seed lot (Baalbaki et al., 2009), whereas the germination test indicates only sharp differences on seed deterioration degree. Hence, the use of vigor tests is of large usefulness on monitoring seed performance during storage, since the drop on seed vigor precedes the viability loss.

Among the several vigor tests available, the cool germination test has presented consistent results on

${ }^{1}$ Submitted on 12/15/2013. Accepted for publication on 02/12/2014.

${ }^{2}$ Departamento de Produção Vegetal, USP/ESALQ, Caixa Postal 9, 13418-900 - Piracicaba, SP, Brasil.

*Corresponding author: < realvarenga7@gmail.com > 
differentiating cotton seed lots. In assessing the correlation among results of tests carried out under laboratory conditions and the emergence of cotton seedling in the field, Freitas et al. (2000) verified that, under adverse conditions, the emergence of seedlings presented a narrow correlation to the seed vigor, which was determined through the cool germination test.

Another vigor test that deserves emphasis is the accelerated aging test, which is one of the most used tests for the assessment of seed physiological potential of several plant species for providing information with high degree of consistency (TeKrony, 1995). Several studies have employed such test to assess vigor of cotton seeds during storage (Medeiros-Filho et al., 1996; Pádua and Vieira, 2001; Freitas et al., 2002).

Although vigor tests are efficient on assessing the seed physiological potential, it is necessary that storage conditions are adequate for that there is preservation of their physiological potential. The cotton seeds are rich in oil $(25 \%$ to $40 \%$ ), and require special care during storage for that their quality is maintained (Passos, 1977; Medeiros-Filho et al., 1996). Such seeds, which are classified as aleuro-oleaginous, have a lower storage potential than the amylaceous seeds due to the low chemical stability of the lipids in relation to starch, since a moderate elevation of the temperature is sufficient for the decomposition of the lipids and increase on deterioration rate as consequence of the respiration process. Therefore, the cotton seeds should be stored with lower moisture content than recommended for amylaceous seeds (11\% to $13 \%)$ (Marcos-Filho, 2005).

Despite availability of several different methods, there is always the opportunity to improve existing methodologies and to include innovative alternatives for assessing seed physiological quality. Thus, the goal is always to promote the standardization, objectivity, and reduction of the time required for performing the tests; as well as improving repeatability of the information provided by such tests (Marcos-Filho, 2010).

In searching for alternatives to improve the assessment of seed physiological potential, and in response to technological advances occurred in recent years, new computerized methods for assessing seed vigor have been developed. On this issue, Sako et al. (2001) developed the software Seed Vigor Imaging System $\left(\mathrm{SVIS}^{\circledR}\right)$, which is a system for determining the vigor of lettuce seeds through computerized images analysis of the seedlings. The system has already been successfully used for seed of other crop species, such as: soybean [Glycine max (L.) Merr.] (Hoffmaster et al., 2005; Marcos-Filho et al., 2009); corn (Zea mays L.) (Hoffmaster et al., 2005; Otoni and McDonald, 2005), melon (Cucumis melo L.) (Marcos-Filho et al., 2006), sweet corn (Zea mays L. var. saccharata Bailey) (Gomes-Junior et al., 2009; Alvarenga et al., 2012), cucumber
(Cucumis sativus L.) (Chiquito et al., 2012); wheat (Triticum aestivum L.) (Silva et al., 2012a); and sunn-hemp (Crotalaria juncea L.) (Silva et al., 2012b). However, there is still no information on the efficiency of analyses performed by the software SVIS ${ }^{\circledR}$ on assessing physiological potential of cotton seeds.

Hence, this study was aimed at evaluating the efficiency of different tests used to differentiate the vigor of cotton seeds; as well to detect possible decreases on seed physiological potential during storage, including results obtained by the computerized analysis of images performed through the software SVIS ${ }^{\circledR}$.

\section{Material and Methods}

The study was performed at the Seed Testing Laboratory and at the Image Analysis Laboratory, Department of Plant Production, of College of Agriculture "Luiz de Queiroz", University of São Paulo (USP/ESALQ), Piracicaba, São Paulo state, Brazil.

The seeds used in the experiments were originating from five different cotton seed lots, cv. BRS 293, previously treated with the fungicide Vitavax-Thiram 200 SC, at a dosage of 250 $\mathrm{mL} .100 \mathrm{Kg}^{-1}$ seed. After treatment, the seeds were packaged into Kraft paper bags and stored for eight months into a cold and dry chamber, under controlled environmental conditions of $10{ }^{\circ} \mathrm{C}$ and $30 \% \mathrm{RH}$ [environment 1 (E1)], as well as in the laboratory, under non-controlled environmental conditions [environment 2 (E2)].

Assessments of seed moisture content and seed performance were carried out in five different periods, with approximately two month intervals, through the following determinations:

Moisture content - was determined by the oven method at $105{ }^{\circ} \mathrm{C} \pm 3{ }^{\circ} \mathrm{C}$, for $24 \mathrm{~h}$ (Brasil, 2009), prior to start of germination and vigor tests, with two replications of to each seed lot. Results were expressed as the mean percent germination (wet basis) to each lot;

Germination test - was conducted with four replications of 50 seeds each, and carried out inside paper towel rolls moistened with water, in an volume equivalent to 2.4 times the mass of the dry substrate, at $25^{\circ} \mathrm{C}$ for seven days. The counts of germinated seeds were performed at the fourth and seventh day after test start, following recommendations established by the Rules for Seed Testing (Brasil, 2009). Results were expressed as the mean percent of normal seedlings emerged to each seed lot;

First germination count - was computed during germination test, considering only the percentage of normal seedlings emerged at the fourth day after sowing; 
Cool germination - this test was carried out following the same procedure described for the germination test; however, differently, the paper towel rolls were packaged inside plastic bags and maintained into a BOD chamber, at $18{ }^{\circ} \mathrm{C}$, in the dark. Assessments were performed seven days after test installation by computing only the normal seedlings presenting the hypocotyl-root axis bigger or equal to $4 \mathrm{~cm}$ (Baalbaki et al., 2009). Results were expressed as the mean percent of normal seedlings emerged to each seed lot;

Accelerated aging test (traditional and saturated salt) these two tests were performed in transparent plastic germination boxes $(11 \mathrm{~cm} \times 11 \mathrm{~cm} \times 3 \mathrm{~cm})\left(G^{-r b o x}{ }^{\circledR}\right)$, in which seeds were evenly distributed in single layer upon a metallic screen fastened in their inner part to hold the seeds; and then at bottom of each Gerbox were added $40 \mathrm{~mL}$ water or saturated $\mathrm{NaCl}$ (Jianhua and McDonald, 1996). Immediately after, the Gerbox were lidded and kept into a BOD chamber, set at $41^{\circ} \mathrm{C}$, for $48 \mathrm{~h}$ to the traditional procedure and $72 \mathrm{~h}$ to the saturated $\mathrm{NaCl}$. After these aging periods the moisture content was also determined aiming at verifying uniformity of test conditions;

Field seedling emergence - this test was carried out at the end of all storage periods assessed; and at every of these periods the seeds were stored into a cold and dry chamber, set to $10{ }^{\circ} \mathrm{C}$ and $30 \%$ UR to prevent the advancement of deterioration process, as well as to avoid interference of this process on results. The experiment was conducted with four replications of 50 seeds each, which were sown into rows of $4 \mathrm{~m}$ long and $40 \mathrm{~cm}$ interspaces; and seeds were then evenly distributed in furrows of about $3 \mathrm{~cm}$ deep and covered with soil. Seedling emergence was assessed at 14 days after sowing, using as evaluation criterion the full expansion of the cotyledonary leaves. Results were expressed as mean percentage of normal seedlings emerged to each seed lot;

Computerized image analysis of seedlings (SVIS $\left.{ }^{\circledR}\right)$ - the seedlings used for this analysis were obtained from four replications of 25 seeds each, to each seed lot, which were evenly distributed in the upper third of the paper towel sheet and put to germinate, at $25^{\circ} \mathrm{C}$, for three days. Subsequently, the seedlings (normal and abnormal), as well as the non-germinated seeds, were transferred to a sheet of black Bristol paper. Soon after, this sheet was placed in a scanner (brand HP; model Scanjet $2410^{\circledR}$ ), fastened upside-down inside an aluminum box with dimensions of $60 \mathrm{~cm} \times 50 \mathrm{~cm} \times 12 \mathrm{~cm}$ and operated by the software Photosmart $^{\circledR}$, with resolution of 100 dpi. The seedlings and the non-germinated seeds were then scanned and analyzed with the aid of the software Seed Vigor Imaging System (SVIS ${ }^{\circledR}$ ); thus obtaining the mean values for the seed vigor index, and the uniformity of development and length of seedlings for every seed lot and cultivar assessed (Hoffmaster et al., 2005).
Statistical procedures: for tests carried out in laboratory a completely randomized experimental design was used; and for the experiment conducted in the field it was used a randomized blocks experimental design, with treatments arranged in a factorial $5 \times 5$ ( 5 seed lots $\times 5$ storage periods). The effect of the interactions between seed lots $\mathrm{x}$ storage periods was assessed separately for each cultivar and storage environment. The means computed for all experiments were compared by Tukey test $(\mathrm{p} \leq 0.05)$.

\section{Results and Discussion}

The seed lots have shown differences on initial seed moisture content ranging between $8.0 \%$ and $8.1 \%$. However, after storage under the controlled conditions of E1, these differences have ranged from $6.3 \%$ to $7.3 \%$. Nevertheless, when seeds were stored under conditions of the E2, the differences on moisture content have reached values between $9.2 \%$ and $11.4 \%$. Thus, due to the differences in this parameter, for the seeds stored in both environments, it was necessary to standardize seed moisture content before starting every assessment period. Such procedure is extremely important for adequately performing vigor tests, since seed moisture content uniformity is essential both for standardization of assessments, as well as for obtaining consistent results (Marcos-Filho, 1999a; TeKrony, 2003).

Despite effects of interaction between the two environments (E1 x E2) on the seed vigor has not been statistically assessed, it was observed that there were no relevant differences among the vigor levels of seeds stored in both environmental conditions, as it may be verified through results presented on Tables 1, 2 and 3. As the E1 features a combination of low temperature $\left(10^{\circ} \mathrm{C}\right)$, and low relative humidity $(30 \%)$, which is suitable for seed storage, it was assumed that, when stored under such environmental conditions, the seeds presented best performance. However, possibly due to high seed physiological potential and the quite favorable environmental conditions of E2 environment, where the mean temperature varied between $19.9{ }^{\circ} \mathrm{C}$ and $25.9{ }^{\circ} \mathrm{C}$ and the relative humidity ranged from $54.7 \%$ to $74.9 \%$, such differences were not significant.

In assessing germination data, obtained in the two environments (E1 and E2), it was found that there were differences among seed lots only after eight months storage in the E1, wherein the lot 3 has had underperformance in relation to lot 5 (Table 1). According to Marcos-Filho (1999b) the use of lots containing seeds with germination similar and above the minimum established for commercialization, it is recommended that these lots are compared through seed performance, as assessed by vigor tests. 
Table 1. Percentages of germination, first germination count and cool germination obtained from seeds of five different cotton seed lots (cv. BRS 293), before and after 2, 4, 6 and 8 storage months in cold and dry chamber (E1) and natural environment (E2).

\begin{tabular}{|c|c|c|c|c|c|c|c|c|c|c|}
\hline \multirow{4}{*}{ Seed lot } & \multicolumn{10}{|c|}{ Parameter assessed / Environmental conditions / Storage period* } \\
\hline & \multicolumn{10}{|c|}{ Germination $(\%)$} \\
\hline & \multicolumn{5}{|c|}{ COLD AND DRY CHAMBER (E1) } & \multicolumn{5}{|c|}{ NATURAL ENVIRONMENT (E2) } \\
\hline & Initial & 2 months & 4 months & 6 months & 8 months & Initial & 2 months & 4 months & 6 months & 8 months \\
\hline 1 & $97 \mathrm{Aa}$ & $95 \mathrm{Aa}$ & $94 \mathrm{Aa}$ & $93 \mathrm{Aa}$ & $93 \mathrm{ABa}$ & $97 \mathrm{Aa}$ & $94 \mathrm{Aab}$ & 93 Aabc & $90 \mathrm{Abc}$ & $89 \mathrm{Ac}$ \\
\hline 2 & $94 \mathrm{Aa}$ & $92 \mathrm{Aa}$ & $93 \mathrm{Aa}$ & $93 \mathrm{Aa}$ & $92 \mathrm{ABa}$ & 94 Аа & $93 \mathrm{Aa}$ & $91 \mathrm{Aa}$ & $90 \mathrm{Aa}$ & $91 \mathrm{Aa}$ \\
\hline 3 & $95 \mathrm{Aa}$ & $93 \mathrm{Aab}$ & $94 \mathrm{Aab}$ & $92 \mathrm{Aab}$ & $89 \mathrm{Bb}$ & 95 Aa & $93 \mathrm{Aa}$ & $87 \mathrm{Aab}$ & $89 \mathrm{Aab}$ & $85 \mathrm{Ab}$ \\
\hline 4 & $96 \mathrm{Aa}$ & $94 \mathrm{Aa}$ & $93 \mathrm{Aa}$ & $93 \mathrm{Aa}$ & $94 \mathrm{ABa}$ & 96 Аа & $95 \mathrm{Aa}$ & $91 \mathrm{Aa}$ & $91 \mathrm{Aa}$ & $91 \mathrm{Aa}$ \\
\hline 5 & $97 \mathrm{Aa}$ & $93 \mathrm{Aa}$ & $95 \mathrm{Aa}$ & $95 \mathrm{Aa}$ & $97 \mathrm{Aa}$ & 97 Аа & $96 \mathrm{Aa}$ & $93 \mathrm{Aa}$ & $94 \mathrm{Aa}$ & $91 \mathrm{Aa}$ \\
\hline $\mathrm{CV}(\%)$ & & & 3.1 & & & & & 3.8 & & \\
\hline \multirow{3}{*}{ Seed lot } & \multicolumn{10}{|c|}{ First germination count $(\%)$} \\
\hline & \multicolumn{5}{|c|}{ COLD AND DRY CHAMBER (E1) } & \multicolumn{5}{|c|}{ NATURAL ENVIRONMENT (E2) } \\
\hline & Initial & 2 months & 4 months & 6 months & 8 months & Initial & 2 months & 4 months & 6 months & 8 months \\
\hline 1 & $94 \mathrm{Aa}$ & $91 \mathrm{Aab}$ & $93 \mathrm{Aab}$ & $92 \mathrm{Aab}$ & $88 \mathrm{Bb}$ & $94 \mathrm{Aa}$ & $96 \mathrm{Aa}$ & $92 \mathrm{Aab}$ & $90 \mathrm{ABab}$ & $89 \mathrm{Ab}$ \\
\hline 2 & $90 \mathrm{Aa}$ & $89 \mathrm{Aa}$ & $92 \mathrm{Aa}$ & $92 \mathrm{Aa}$ & $85 \mathrm{Bb}$ & $90 \mathrm{Aa}$ & $90 \mathrm{Aa}$ & $90 \mathrm{Aa}$ & $90 \mathrm{ABa}$ & $87 \mathrm{Aa}$ \\
\hline 3 & $91 \mathrm{Aa}$ & $89 \mathrm{Aa}$ & $90 \mathrm{Aa}$ & $91 \mathrm{Aa}$ & $82 \mathrm{Bb}$ & $91 \mathrm{Aa}$ & $93 \mathrm{Aa}$ & $87 \mathrm{Aab}$ & $86 \mathrm{Bab}$ & $85 \mathrm{Ab}$ \\
\hline 4 & $94 \mathrm{Aa}$ & $91 \mathrm{Aa}$ & $94 \mathrm{Aa}$ & $93 \mathrm{Aa}$ & $86 \mathrm{Bb}$ & 94 Аа & $94 \mathrm{Aa}$ & $92 \mathrm{Aa}$ & $91 \mathrm{ABa}$ & $89 \mathrm{Aa}$ \\
\hline 5 & $94 \mathrm{Aa}$ & $91 \mathrm{Aa}$ & $93 \mathrm{Aa}$ & $94 \mathrm{Aa}$ & $96 \mathrm{Aa}$ & 94 Аa & $91 \mathrm{Aa}$ & $90 \mathrm{Aa}$ & $94 \mathrm{Aa}$ & $91 \mathrm{Aa}$ \\
\hline $\mathrm{CV}(\%)$ & & & 3.5 & & & & & 4.0 & & \\
\hline \multirow{3}{*}{ Seed lot } & \multicolumn{10}{|c|}{ Cool germination $(\%)$} \\
\hline & \multicolumn{5}{|c|}{ COLD AND DRY CHAMBER (E1) } & \multicolumn{5}{|c|}{ NATURAL ENVIRONMENT (E2) } \\
\hline & Initial & 2 months & 4 months & 6 months & 8 months & Initial & 2 months & 4 months & 6 months & 8 months \\
\hline 1 & $77 \mathrm{ABa}$ & $78 \mathrm{ABa}$ & $81 \mathrm{ABa}$ & $79 \mathrm{ABa}$ & $77 \mathrm{ABa}$ & $77 \mathrm{ABa}$ & $82 \mathrm{ABa}$ & $79 \mathrm{ABa}$ & $79 \mathrm{ABa}$ & $73 \mathrm{BCa}$ \\
\hline 2 & $77 \mathrm{ABa}$ & $79 \mathrm{ABa}$ & $80 \mathrm{ABa}$ & $81 \mathrm{ABa}$ & $73 \mathrm{ABa}$ & $77 \mathrm{ABa}$ & $80 \mathrm{ABa}$ & $78 \mathrm{ABa}$ & $79 \mathrm{ABa}$ & $74 \mathrm{ABCa}$ \\
\hline 3 & $73 \mathrm{Ba}$ & $75 \mathrm{Ba}$ & $72 \mathrm{Ba}$ & $75 \mathrm{Ba}$ & $68 \mathrm{Ba}$ & $73 \mathrm{Ba}$ & $78 \mathrm{Ba}$ & $76 \mathrm{Ba}$ & $75 \mathrm{Ba}$ & $69 \mathrm{Ca}$ \\
\hline 4 & $78 \mathrm{ABa}$ & $81 \mathrm{ABa}$ & $82 \mathrm{ABa}$ & $81 \mathrm{ABa}$ & $77 \mathrm{ABa}$ & $78 \mathrm{ABa}$ & $85 \mathrm{ABa}$ & $81 \mathrm{ABa}$ & $80 \mathrm{ABa}$ & $79 \mathrm{ABa}$ \\
\hline 5 & $86 \mathrm{Aa}$ & $87 \mathrm{Aa}$ & $88 \mathrm{Aa}$ & $87 \mathrm{Aa}$ & $80 \mathrm{Aa}$ & $86 \mathrm{Aa}$ & $88 \mathrm{Aa}$ & $86 \mathrm{Aa}$ & $84 \mathrm{Aa}$ & $82 \mathrm{Aa}$ \\
\hline $\mathrm{CV}(\%)$ & & & 6.6 & & & & & 5.8 & & \\
\hline
\end{tabular}

*Means followed by the same uppercase letter in the columns, and lower case letter on the lines, within each environment, do not statistically differ between each other by Tukey test $(\mathrm{p} \leq 0.05) ; \mathrm{E}=$ environment.

It was also observed that, in the E1, only the seeds of lot 3 showed significant decreases on germination, which was reduced from $95 \%$ to $89 \%$ throughout eight storage months (Table 1); but in the E2, such reduction was more evident for the seeds of lots 1 and 3. Nevertheless, it is important to emphasize that this sharp decrease on germination has occurred at the end of the storage period (at 6 months, for seeds of the lot 1; and at 8 months, for seeds of lot 3 ). However, the seeds of all lots assessed kept their high germination percentage, i.e., higher than the minimum percentage of $75 \%$ required for the marketing of cotton seeds (Brasil, 2005); thus demonstrating the high physiological potential of the seeds used in this study.

On assessing first germination count, it was found that there were statistically significant differences among means obtained for percent germination only at the end of storage period (Table 1). Nevertheless, the highest vigor level for seeds of lot 5, in the E1, was detected only at the eighth month storage; but, from six storage months in E2, the seeds of lot 3 already showed lower values for such parameter (Table 1). These results demonstrate the high potential performance of seeds, when they were germinated under favorable environmental conditions; thus hindering separation of lots into different vigor levels.

As it may be seen through data shown on Table 1, after the eight months storage, the decrease on seed percent germination was more evident for lots 1, 2, 3, and 4, when they were stored under conditions of the E1; as well as for seeds of lots 1 and 3, stored under conditions of the E2. About this same theme, Delouche and Baskin (1973) have found that reduction on percent seed germination is not included among events occurring at the start of the seed deterioration process. 
It is known that cool germination test, due to its high efficiency is the most widely used to evaluate vigor of cotton seeds. In this study, the efficiency of such test has been proven, since it was found significant statistical differences among vigor levels of seeds of all lots, in all evaluation periods and in both studied environmental conditions; thereby ratifying the highest vigor of the lot 5 seeds, in relation to the lot 3 , when seeds were assessed through this test (Table 1). This fact proves its high sensitivity to evaluate physiological potential of cotton seeds during storage. Similar results have already been found by Freitas et al. (2000), who also verified that the cool germination test was shown to be efficient on evaluating vigor of cotton seeds allowing the lots stratification in vigor levels since the beginning of storage.

Moreover, it was also found that, although the germination percent has been lower than the germination percent obtained by the other tests, the performance of seeds from all seed lots was similar throughout all the eight storage months period, both in E1 as in E2 (Table 1). However, in contrast, Pádua et al. (2002) have found that seeds of two cotton seed lots, stored for 12 months in an environment without temperature and relative humidity control, have had decreased vigor already from the second storage month. Nevertheless, the reasons for these differences on results are evident, as storage environmental conditions, the cultivars assessed, as well as initial physiological potential of seeds were not the same used in this study.

As to accelerated aging tests (traditional and saturated salt) (Table 2), it was observed that, generally, the variations on seed moisture content were within tolerated levels and did not affect the behavior of seeds during tests; since after the eight storage months, seeds of lots stored in E1 showed differences between 0.9 and 2.5 percentage points on moisture content and when stored in E2, these differences varied between 0.7 and 2.3 percentage points, after aging.

Table 2. Traditional and saturated salt accelerated aging tests and field seedling emergence originating from five cotton seed lots, cv. BRS 293, before and after 2, 4, 6 and 8 months of storage in cold and dry chamber (E1) and natural environment (E2).

\begin{tabular}{|c|c|c|c|c|c|c|c|c|c|c|}
\hline \multirow{3}{*}{$\begin{array}{c}\text { Seed } \\
\text { lot }\end{array}$} & \multicolumn{10}{|c|}{ Traditional Accelerated Aging (\%) } \\
\hline & \multicolumn{5}{|c|}{ COLD AND DRY CHAMBER (E1) } & \multicolumn{5}{|c|}{ NATURAL ENVIRONMENT (E2) } \\
\hline & Initial & 2 months & 4 months & 6 months & 8 months & Initial & 2 months & 4 months & 6 months & 8 months \\
\hline 1 & $94 \mathrm{Aa}$ & 94Aa & $93 \mathrm{Aa}$ & $90 \mathrm{ABa}$ & $90 \mathrm{ABa}$ & 94Aa & $94 \mathrm{ABa}$ & $90 \mathrm{ABab}$ & $87 \mathrm{ABb}$ & $87 \mathrm{ABb}$ \\
\hline 2 & 94Aa & $93 \mathrm{Aa}$ & $91 \mathrm{Aa}$ & $87 \mathrm{BCb}$ & $86 \mathrm{BCb}$ & 94Aa & $94 \mathrm{ABa}$ & $88 \mathrm{BCb}$ & $86 \mathrm{ABb}$ & $86 \mathrm{ABb}$ \\
\hline 3 & $93 \mathrm{Aa}$ & $88 \mathrm{Bab}$ & 86Bab & $84 \mathrm{Cb}$ & $84 \mathrm{Cb}$ & 93Aa & $90 \mathrm{Ba}$ & $84 \mathrm{Cb}$ & $82 \mathrm{Bb}$ & $84 \mathrm{Bb}$ \\
\hline 4 & $95 \mathrm{Aa}$ & 97Aa & $93 \mathrm{Aab}$ & $89 \mathrm{ABCb}$ & $90 \mathrm{ABb}$ & $95 \mathrm{Aa}$ & $94 \mathrm{ABa}$ & $91 \mathrm{ABab}$ & $86 \mathrm{ABb}$ & $87 \mathrm{ABb}$ \\
\hline 5 & $94 \mathrm{Aa}$ & 96Aa & $95 \mathrm{Aa}$ & 93Aa & 94Aa & 94Aa & 96Aa & 94Aa & 91Aa & 91Aa \\
\hline CV (\%) & & & 3.2 & & & & & 2.9 & & \\
\hline \multirow{3}{*}{$\begin{array}{c}\text { Seed } \\
\text { lot }\end{array}$} & \multicolumn{10}{|c|}{ Saturated Salt Accelerated Aging (\%) } \\
\hline & \multicolumn{5}{|c|}{ COLD AND DRY CHAMBER (E1) } & \multicolumn{5}{|c|}{ NATURAL ENVIRONMENT (E2) } \\
\hline & Initial & 2 months & 4 months & 6 months & 8 months & Initial & 2 months & 4 months & 6 months & 8 months \\
\hline 1 & $94 \mathrm{Aa}$ & $94 \mathrm{ABa}$ & $91 \mathrm{ABab}$ & $88 \mathrm{ABb}$ & $88 \mathrm{BCb}$ & 94Aa & $95 \mathrm{Aa}$ & $89 \mathrm{ABb}$ & $89 \mathrm{ABb}$ & $89 \mathrm{ABb}$ \\
\hline 2 & $94 \mathrm{Aa}$ & $90 \mathrm{ABab}$ & $90 \mathrm{ABab}$ & $89 \mathrm{ABb}$ & $88 \mathrm{BCb}$ & 94Aa & $91 \mathrm{Aab}$ & $85 \mathrm{ABb}$ & $88 \mathrm{ABb}$ & $85 \mathrm{ABb}$ \\
\hline 3 & $93 \mathrm{Aa}$ & 89Bab & $82 \mathrm{Bb}$ & $85 \mathrm{Bb}$ & $84 \mathrm{Cb}$ & 93Aa & 91Aa & $81 \mathrm{Bb}$ & $83 \mathrm{Bb}$ & $82 \mathrm{Bb}$ \\
\hline 4 & $92 \mathrm{Aa}$ & $94 \mathrm{ABa}$ & $91 \mathrm{ABa}$ & $89 \mathrm{ABa}$ & $90 \mathrm{ABa}$ & 92Aa & $95 \mathrm{Aa}$ & $88 \mathrm{ABb}$ & $89 \mathrm{ABb}$ & $87 \mathrm{ABb}$ \\
\hline 5 & $94 \mathrm{Aa}$ & $95 \mathrm{Aa}$ & 94Aa & 94Aa & 94Aa & 94Aa & 94Aa & 91Aa & 93Aa & 91Aa \\
\hline CV (\%) & & & 2.9 & & & & & 3.6 & & \\
\hline \multirow{3}{*}{$\begin{array}{c}\text { Seed } \\
\text { lot }\end{array}$} & \multicolumn{10}{|c|}{ Field Seedling Emergence (\%) } \\
\hline & \multicolumn{5}{|c|}{ COLD AND DRY CHAMBER (E1) } & \multicolumn{5}{|c|}{ NATURAL ENVIRONMENT (E2) } \\
\hline & Initial & 2 months & 4 months & 6 months & 8 months & Initial & 2 months & 4 months & 6 months & 8 months \\
\hline 1 & $89 \mathrm{BCa}$ & $90 \mathrm{Aa}$ & $92 \mathrm{ABa}$ & $92 \mathrm{ABa}$ & $91 \mathrm{ABa}$ & $89 \mathrm{BCa}$ & $93 \mathrm{ABa}$ & $91 \mathrm{ABa}$ & $92 \mathrm{ABa}$ & $87 \mathrm{ABa}$ \\
\hline 2 & $89 \mathrm{BCa}$ & 89Aa & $90 \mathrm{ABa}$ & $90 \mathrm{ABa}$ & $91 \mathrm{ABa}$ & $89 \mathrm{BCa}$ & $92 \mathrm{ABa}$ & $92 \mathrm{ABa}$ & $92 \mathrm{ABa}$ & $89 \mathrm{ABa}$ \\
\hline 3 & $88 \mathrm{Ca}$ & $91 \mathrm{Aa}$ & $85 \mathrm{Ba}$ & $86 \mathrm{Ba}$ & $86 \mathrm{Ba}$ & $88 \mathrm{Ca}$ & $87 \mathrm{Ba}$ & $86 \mathrm{Ba}$ & $88 \mathrm{Ba}$ & $82 \mathrm{Ba}$ \\
\hline 4 & $95 \mathrm{ABa}$ & 89Aa & $92 \mathrm{ABa}$ & $91 \mathrm{ABa}$ & $92 \mathrm{ABa}$ & $95 \mathrm{ABa}$ & $89 \mathrm{ABab}$ & $93 \mathrm{ABab}$ & $93 \mathrm{ABab}$ & $88 \mathrm{ABb}$ \\
\hline 5 & $97 \mathrm{Aa}$ & $93 \mathrm{Aa}$ & $95 \mathrm{Aa}$ & 94Aa & $95 \mathrm{Aa}$ & 97Aa & 94Aa & 96Aa & 96Aa & $92 \mathrm{Aa}$ \\
\hline CV (\%) & & & 4.2 & & & & & 3.8 & & \\
\hline
\end{tabular}

* Means followed by the same uppercase letter in the columns, and lower case letter on the lines, within each environment, do not statistically differ between each other by Tukey test $(\mathrm{p} \leq 0.05)$. 
Furthermore, it was also found that, from the second month, under both storage conditions, the seeds of lot 5 have had higher performance in relation to seeds of lot 3 (Table 2); thereby agreeing to results obtained by tests of germination, first germination count and cool germination. It was also found that, for most lots, this test was able to detect the differences on reduction of seed vigor throughout all the storage period. When stored under the conditions of E1, seeds of the lots 2, 3 and 4 have had reduction on physiologic potential only after the sixth or the eighth month. However, when seed were stored under the conditions of E2 there was reduction on physiological potential already from the fourth months, for seeds of lots 2 and 3; and after the sixth months, for seeds of the lots 1 and 4 (Table 2). On assessing seed physiological potential through traditional accelerated aging test, other researchers have also verified reduction on vigor of cotton seeds, during storage, especially under noncontrolled environmental conditions (Medeiros-Filho et al., 1996; Freitas et al., 2000; Pádua and Vieira, 2001; Silva et al., 2006); since under such environmental conditions, the seeds are exposed to the fluctuations of temperature and relative humidity, which also contribute to reduction of seed physiological potential.

By the mean values obtained by the saturated salt accelerated aging test, it was possible to sort seed lots by vigor levels (Table 2). After the second storage month, under environmental conditions of E1, the seeds of lot 5 showed again the higher level of vigor than seeds of lot 3 . The same sorting can be applied to seeds stored under the E2, since fourth storage month. However, for the seeds of lots 1 and 2, the reduction in germination percentage in E1 was statistically significant only after the sixth month of storage, but for the seeds of lot 3 , this reduction was already significant after the fourth month. Nevertheless, when stored in the environmental conditions of E2, the seeds of lots 1, 2, 3 and 4 showed significant decrease on the vigor from the fourth storage month. The seeds of lot 5 have retained their high physiological potential statistically the same in the two environmental conditions studied throughout the storage period (Table 2).

Through the field seedling emergence test it was also feasible to sort the seed lots by the vigor of their seeds, for in all the storage periods and environmental conditions assessed, the results confirmed the best performance of seeds of the lot 5 in relation to the seeds of lot 3 ; except on second storage period in the environmental conditions of E1 (Table 2). However, for both environmental conditions studied (E1 and E2), the seeds of other seed lots have kept a relatively uniform performance throughout all storage periods; except the seeds of lot 4 stored in the conditions of E2, in which the percentage of seedling emergence in the field was reduced from $95 \%$ (before storage) to $88 \%$ after eight months of storage. Such results demonstrate that the storage conditions evaluated in this study were adequate for maintenance of seed physiological potential.

On Table 3 are the results of analyzes SVIS $^{\circledR}$. Evaluating the data concerning the vigor index, it was found the worse performance of lot 3 in relation to lot 5 , after 6 months of storage into cold and dry chamber (E1), and from 4 months in the natural environment (E2). Moreover, the seeds of lot 3, stored in cold and dry chamber (E1) showed a reduced rate of vigor from 6 months of storage; when stored in natural environment (E2), lots 3 and 4 have had their vigor index reduced after 4 months of storage, and lots 1 and 2 from 6 months.

Through data obtained by the development uniformity index shown on Table 3 it can be seen that, under the E1 environmental conditions, the seeds of lot 3 showed the worst performance already from the second storage month; and that seeds of lot 5 have shown the best performance, only after six months of storage. Yet, under E2 environmental conditions, the index value for seed development uniformity of the lot 3 was already the lowest from the second storage month; whereas the seeds of lot 5 showed the highest uniformity index throughout the two and eight storage months. However, other studies on the use of the software SVIS $^{\circledR}$ to assess the seed physiological potential have shown that the development uniformity index was not sufficiently sensitive to allow distinction between different seed lots of soybean (Marcos-Filho et al., 2009; Santos et al., 2011), cucumber (Chiquito et al., 2012), and wheat (Silva et al., 2012a); but was efficient to assess vigor level of seeds of melon (Marcos-Filho et al., 2006) and sunn hemp (Silva et al., 2012b).

As far as the seedlings length, results revealed significant differences among the lots from 2 months of storage in cold and dry chamber (E1), and after 4 months in the natural environment (E2), identifying, once more, the lot 3 as the less vigorous in relation to lot 5 . According to Nakagawa (1999), the tests used to assess the growth of seedlings are the best suited to detect differences in the physiological potential of seeds of other several species of cultivated plants.

It was also observed that, under the E1 environmental conditions there was a statistically significant decrease on the length of seedlings, originating from the seeds of the lots 3 and 4, only from the sixth month of storage; and that under the E2 environmental conditions, such decrease already occurred after the fourth storage month. 
Table 3. Vigor index, development uniformity and seedlings length, determined by the Seed Vigor Imaging System (SVIS $\left.{ }^{\circledR}\right)$ on cotton seeds, cv. BRS 293, originating from five different lots and assessed before and after 2, 4, 6 and 8 months of storage in cold and dry chamber (E1) and natural environment (E2).

\begin{tabular}{|c|c|c|c|c|c|c|c|c|c|c|}
\hline \multirow{4}{*}{ Seed lot } & \multicolumn{10}{|c|}{ Parameter Assessed / Environmental Conditions / Storage Period* } \\
\hline & \multicolumn{10}{|c|}{ Vigor index } \\
\hline & \multicolumn{5}{|c|}{ COLD AND DRY CHAMBER (E1) } & \multicolumn{5}{|c|}{ NATURAL ENVIRONMENT (E2) } \\
\hline & Before & 2 months & 4 months & 6 months & 8 months & Before & 2 months & 4 months & 6 months & 8 months \\
\hline 1 & 774Aa & 794Aa & 751Aa & $741 \mathrm{ABa}$ & $721 \mathrm{ABa}$ & 774Aa & $813 \mathrm{Aa}$ & $786 \mathrm{ABa}$ & $770 \mathrm{ABb}$ & $740 \mathrm{ABb}$ \\
\hline 2 & 807Aa & $828 \mathrm{Aa}$ & 836Aa & $772 \mathrm{ABa}$ & $757 \mathrm{ABa}$ & 807Aa & $841 \mathrm{Aa}$ & $792 \mathrm{ABa}$ & $786 \mathrm{ABb}$ & $767 \mathrm{ABb}$ \\
\hline 3 & $801 \mathrm{Aa}$ & 818Aa & 762Aab & $694 \mathrm{Bb}$ & $669 \mathrm{Bb}$ & 801Aa & 811Aa & $727 \mathrm{Bb}$ & $720 \mathrm{Bb}$ & $703 \mathrm{Bc}$ \\
\hline 4 & 796Aa & $751 \mathrm{Aa}$ & 824Aa & $762 \mathrm{ABa}$ & 737ABa & 796Aa & $864 \mathrm{Aa}$ & $777 \mathrm{ABb}$ & $775 \mathrm{ABb}$ & $750 \mathrm{ABb}$ \\
\hline 5 & 791Aa & 834Aa & 836Аa & 814Aa & $772 \mathrm{Aa}$ & 791Aa & $860 \mathrm{Aa}$ & $810 \mathrm{Aa}$ & $805 \mathrm{Aa}$ & 812Aa \\
\hline \multirow[t]{2}{*}{ CV $(\%)$} & \multicolumn{5}{|c|}{6.1} & \multicolumn{5}{|c|}{4.7} \\
\hline & \multicolumn{10}{|c|}{ Development uniformity index } \\
\hline \multirow[t]{2}{*}{ Seed lot } & \multicolumn{5}{|c|}{ COLD AND DRY CHAMBER (E1) } & \multicolumn{5}{|c|}{ NATURAL ENVIRONMENT (E2) } \\
\hline & Before & 2 months & 4 months & 6 months & 8 months & Before & 2 months & 4 months & 6 months & 8 months \\
\hline 1 & 859Aa & 869Aa & $862 \mathrm{Aa}$ & $869 \mathrm{ABa}$ & $880 \mathrm{ABa}$ & $859 \mathrm{Ab}$ & 896ABab & $885 \mathrm{Aab}$ & 920Aa & 896ABab \\
\hline 2 & $862 \mathrm{Aa}$ & $880 \mathrm{Aa}$ & $873 \mathrm{Aa}$ & $843 \mathrm{ABb}$ & $875 \mathrm{ABa}$ & $862 \mathrm{Ab}$ & $887 \mathrm{ABab}$ & 880Aab & 907Aa & $866 \mathrm{Bab}$ \\
\hline 3 & $863 \mathrm{Aa}$ & $811 \mathrm{Ba}$ & $802 \mathrm{Bb}$ & $775 \mathrm{Cb}$ & $815 \mathrm{Cab}$ & $863 \mathrm{Aa}$ & $882 \mathrm{Ba}$ & $818 \mathrm{Bb}$ & 878Aa & $804 \mathrm{Cb}$ \\
\hline 4 & 850Aab & $880 \mathrm{Aa}$ & 868Aa & $811 \mathrm{BCb}$ & 856BCab & $850 \mathrm{Ab}$ & $902 \mathrm{ABa}$ & $885 \mathrm{Aab}$ & $901 \mathrm{Aa}$ & $873 \mathrm{Bab}$ \\
\hline 5 & $891 \mathrm{Aa}$ & $884 \mathrm{Aa}$ & 900Aa & $892 \mathrm{Aa}$ & $921 \mathrm{Aa}$ & $891 \mathrm{Aa}$ & 930Aa & $901 \mathrm{Aa}$ & 916Aa & $922 \mathrm{Aa}$ \\
\hline $\mathrm{CV}(\%)$ & & & 3.2 & & & & & 2.5 & & \\
\hline \multirow{3}{*}{ Seed lot } & \multicolumn{10}{|c|}{ Seedlings length $(\mathrm{cm})$} \\
\hline & \multicolumn{5}{|c|}{ COLD AND DRY CHAMBER (E1) } & \multicolumn{5}{|c|}{ NATURAL ENVIRONMENT (E2) } \\
\hline & Before & 2 months & 4 months & 6 months & 8 months & Before & 2 months & 4 months & 6 months & 8 months \\
\hline 1 & 7.3Aa & $7.5 \mathrm{ABa}$ & $6.9 \mathrm{BCa}$ & $6.5 \mathrm{ABa}$ & $6.4 \mathrm{ABa}$ & $7.3 \mathrm{Aa}$ & 7.7Aa & $7.5 \mathrm{ABa}$ & $6.8 \mathrm{ABa}$ & $6.8 \mathrm{ABa}$ \\
\hline 2 & 7.8Aa & 7.9ABa & 8.0ABa & $6.9 \mathrm{ABa}$ & 7.0ABa & 7.8Aa & 7.8Aa & $7.5 \mathrm{ABa}$ & $7.0 \mathrm{ABa}$ & 7.0ABa \\
\hline 3 & 7.7Aa & $6.6 \mathrm{Bab}$ & $6.6 \mathrm{Cab}$ & $5.7 \mathrm{Bb}$ & $5.4 \mathrm{Bb}$ & 7.7Aa & 7.9Aa & $6.2 \mathrm{Bb}$ & $6.7 \mathrm{Bb}$ & $6.1 \mathrm{Bb}$ \\
\hline 4 & 7.4Aa & 7.7ABa & 7.7ABCa & $6.4 \mathrm{ABb}$ & $6.7 \mathrm{ABb}$ & 7.4Aa & 8.3Aa & 7.0ABb & 7.3ABb & $6.9 \mathrm{ABb}$ \\
\hline 5 & 7.6Aa & 8.1Aa & 8.3Aa & 7.1Aa & $7.5 \mathrm{Aa}$ & 7.6Aa & $8.4 \mathrm{Aa}$ & 7.7Aa & 7.6Aa & 7.8Aa \\
\hline CV (\%) & \multicolumn{5}{|c|}{8.7} & \multicolumn{5}{|c|}{7.0} \\
\hline
\end{tabular}

*Means followed by the same uppercase letter in the columns, and lower case letter on the lines, within each environment, do not statistically differ between each other by Tukey test $(\mathrm{p} \leq 0.05)$.

Given the above, it is possible to affirm that, in both storage environments assessed (E1 and E2), the tests of cool germination, accelerated aging traditional and saturated salt, field seedling emergence as well as seedlings length, as measured by the SVIS ${ }^{\circledR}$ software, are highly efficient on differentiating seed vigor; thereby allowing sorting of the seeds of lots 3 and 5 as having the worst and the best performance, respectively; and that, generally, this classification was more evident from the fourth month of storage in both environments assessed. Moreover, it is also possible to affirm that the accelerated aging tests (traditional and with saturated salt), as well as vigor index and seedlings length, as determined by the software SVIS ${ }^{\circledR}$, have shown enough sensitivity to identify decreases on seed vigor; and that, in general, these falls occur from the sixth month of storage under low temperature and relative humidity, and after the fourth month of storage at natural laboratory conditions.

\section{Conclusions}

The tests of cool germination, accelerated aging (traditional and saturated salt), field seedling emergence and SVIS $^{\circledR}$ (seedlings length) are suitable for evaluating cotton seed physiological potential during storage;

The accelerated aging tests (traditional and saturated salt) and the vigor index and seedlings length, assessed by the SVIS ${ }^{\circledR}$, present sensitivity for identifying decreases on the seed vigor during storage.

\section{Acknowledgments}

The authors would like to thank to Coordination of 
Improvement of Higher Education Personnel (CAPES) and to Foundation for Research Support of the State of São Paulo (FAPESP), by the financial support provided to this study.

\section{References}

ALVARENGA, R.O.; MARCOS-FILHO, J.; GOMES JUNIOR, F.G. Avaliação do vigor de sementes de milho superdoce por meio da análise computadorizada de imagens de plântulas. Revista Brasileira de Sementes, v.34, n.3, p.488-494, 2012. http://www.scielo.br/pdf/rbs/v34n3/17.pdf

BAALBAKI, R.; ELIAS, S.; MARCOS-FILHO, J.; MCDONALD, M.B. Seed vigor testing handbook. Ithaca: Association of Official Seed Analysts, 2009. 341p.

BRASIL. Ministério da Agricultura, Pecuária e Abastecimento. Instrução normativa $N^{\circ} 25$, de 16 de dezembro de 2005. Brasília, 2005. Disponível em: $<$ http://extranet.agricultura.gov.br/sislegis-consulta/consultarLegislacao. do $>$. Accessed on Jun. $03^{\text {rd }} 2010$.

BRASIL. Ministério da Agricultura, Pecuária e Abastecimento. Regras para análises de sementes. Ministério da Agricultura, Pecuária e Abastecimento. Secretaria de Defesa Agropecuária. Brasília, DF: Mapa/ACS, 2009. 395p. http://www.agricultura.gov.br/arq_editor/file/Laborat $\%$ C3\%B3rio/Sementes/ Regras\%20para\%20Analise $\% 20 \mathrm{de} \% 20$ Sementes.pdf

CHIQUITO, A.A.; GOMES JUNIOR, F.G.; MARCOS-FILHO, J. Assessment of physiological potential of cucumber seeds using the software Seedling Vigor Imaging System (SVIS $\left.{ }^{\circledR}\right)$. Revista Brasileira de Sementes, v.34, n.2, p.255-263, 2012. http://www.scielo.br/pdf/rbs/v34n2/10.pdf

DELOUCHE, J.C.; BASKIN, C.C. Accelerated aging techniques for predicting the relative storability of seed lots. Seed Science and Technology, v.1, n.2, p.427-452, 1973.

FREITAS, R.A.; DIAS, D.C.F.S.; CECON, P.R.; REIS, M.S.; DIAS, L.A.S. Storability of cotton seeds predicted by vigour tests. Seed Science and Technology, v.30, n.2, p.403-410, 2002.

FREITAS, R.A.; DIAS, D.C.F.S.; CECON, P.R.; REIS, M.S. Qualidade fisiológica e sanitária de sementes de algodão durante o armazenamento. Revista Brasileira de Sementes, v.22, n.2, p.94-101, 2000.

GOMES JUNIOR, F.G.; MONDO, V.H.V.; CICERO, S.M.; MCDONALD, M.B.; BENNETT, M.A. Evaluation of priming effects on sweet corn seeds by SVIS. Seed Technology, v.31, n.1, p.95-100, 2009. http://www. seedtechnology.net/journal/stv311.pdf

HOFFMASTER, A.L.; XU, L.; FUJIMURA, K.; MCDONALD, M.B.; BENNETT, M.A.; EVANS, A.F. The Ohio State University Seed Vigor Imaging System (SVIS) for soybean and corn seedlings. Seed Technology, v.27, n.1, p.724, 2005. http://seedbiology.osu.edu/People_pdf/miller_abstractSVIScorn.pdf

JIANHUA, Z.; MCDONALD, M.B. The saturated salt accelerated aging test for small-seeded crops. Seed Science and Technology, v.25, n.1, p.123-131, 1996.

MARCOS-FILHO, J.; BENNETT, M.A.; MCDONALD, M.B.; EVANS, A.F.; GRASSBAUGH, E.M. Assessment of melon seed vigor by an automated computer imaging system compared to traditional procedures. Seed Science and Technology, v.34, n.2, p.485-497, 2006. http://www.ingentaconnect.com/ content/ista/sst/2006/00000034/00000002/art00023

MARCOS-FILHO, J. Fisiologia de sementes de plantas cultivadas. Piracicaba: FEALQ, 2005. 495p.
MARCOS- FILHO, J.; KIKUTI, A.L.P.; LIMA, L.B. Métodos para avaliação do vigor de sementes de soja, incluindo a análise computadorizada de imagens. Revista Brasileira de Sementes, v.31, n.1, p.102-112, 2009. http:// www.scielo.br/pdf/rbs/v31n1/a12v31n1.pdf

MARCOS-FILHO, J. Sistema computadorizado de análise de imagens de plântulas $\left(\right.$ SVIS $\left.^{\circledR}\right)$ para avaliação do vigor de sementes. Informativo ABRATES, v.20, n.3, p.40-44, 2010. http://www.abrates.org.br/portal/images/ stories/informativos/v20n3/minicurso02.pdf

MARCOS-FILHO, J. Testes de envelhecimento acelerado. In: KRZYZANOWSKI, F.C.; VIEIRA, R.D.; FRANÇA-NETO, J.B. (Ed.). Vigor de sementes: conceitos e testes. Londrina: ABRATES, cap.3, p.1-24, 1999a.

MARCOS-FILHO, J. Testes de vigor: importância e utilização. In: KRZYZANOWSKI, F.C.; VIEIRA, R.D.; FRANÇA-NETO, J.B. (Ed.). Vigor de sementes: conceitos e testes. Londrina: ABRATES, cap.1, p.1-21, 1999b.

MEDEIROS FILHO, S.; FRAGA, A.C.; QUEIROGA, V.P.; SOUSA, L.C.F. Efeito do armazenamento sobre a qualidade fisiológica de sementes deslintadas de algodão. Ciência e Agrotecnologia, v.20, n.3, p.284-292, 1996.

NAKAGAWA, J. Testes de vigor baseados no desempenho das plântulas. In: KRZYZANOWSKI, F.C.; VIEIRA, R.D.; FRANÇA-NETO, J.B. (Ed.). Vigor de sementes: conceitos e testes. Londrina: ABRATES, cap. 2, p.2.1-2.24, 1999.

OTONI, R.R.; MCDONALD, M.B. Moisture and temperature effects on maize and soybean seedlings using the seed vigor imaging system. Seed Technology, v.27, n.2, p.243-247, 2005. http://www.seedtechnology.net/journal/st27no2.pdf

PÁDUA, G.P.; VIEIRA, R.D.; BARBOSA, J.C. Desempenho de sementes de algodão tratadas quimicamente e armazenadas. Revista Brasileira de Sementes, v.24, n.1, p.212-219, 2002. http://www.scielo.br/pdf/rbs/v24n1/v24n1a30.pdf

PÁDUA, G.P.; VIEIRA, R.D. Deterioração de sementes de algodão durante o armazenamento. Revista Brasileira de Sementes, v.23, n.2, p.255-262, 2001.

PASSOS, S.M.G. Algodão. Campinas: Instituto Campineiro de Ensino Agrícola, 1977. 424p.

SANTOS, J.F.; ALVARENGA, R.O.; TIMÓTEO, T.S.; CONFORTO, E.C.; MARCOS FILHO, J.; VIEIRA, R.D. Avaliação do potencial fisiológico de lotes de sementes de soja. Revista Brasileira de Sementes, v. 33, n. 4, p. 743751, 2011. http://www.scielo.br/pdf/rbs/v33n4/16.pdf

SAKO, Y.; MCDONALD, M.B.; FUJIMURA, K.; EVANS, A.F.; BENNETT, M.A. A system for automated seed vigour assessment. Seed Science and Technology, v.29, n.3, p.625-636, 2001. http://cat.inist. fr/?aModele $=$ afficheN\&cpsidt $=14110910$

SILVA, C.B.; LOPES, M.M.; MARCOS-FILHO, J.; VIEIRA, R.D. Automated system of seedling image analysis (SVIS) and electrical conductivity to assess sun hemp seed vigor. Revista Brasileira de Sementes, v.34, n.1, p.55-60, 2012b. http://www.scielo.br/pdf/rbs/v34n1/a07v34n1.pdf

SILVA, J.C.; ALBUQUERQUE, M.C.; MENDONÇA, E.A.F.; KIM, M.E. Desempenho de sementes de algodão após o processamento e armazenamento. Revista Brasileira de Sementes, v.28, n.1, p.79-85, 2006. http://www.scielo. $\mathrm{br} / \mathrm{pdf} / \mathrm{rbs} / \mathrm{v} 28 \mathrm{n} 1 / \mathrm{a} 11 \mathrm{v} 28 \mathrm{n} 1 . \mathrm{pdf}$

SILVA, V.N.; GOMES JUNIOR, F.G.; CICERO, S.M. Computerized imaging analysis of seedlings for assessment of physiological potential of wheat seeds. Revista Brasileira de Sementes, v.34, n.4, p.589-596, 2012a. http://www.scielo.br/pdf/rbs/v34n4/09.pdf 
TEKRONY, D.M. Accelerated aging test. In: HAMPTON, J.G.; TEKRONY, D.M. (Ed.). Handbook of vigour test methods. $3^{\text {rd }}$ Ed. Zurich: International Seed Testing Association, 1995. p.35-50.
TEKRONY, D.M. Precision is an essential component in seed vigour testing. Seed Science and Technology, v.31, n.2, p.435-447, 2003. http://www. ingentaconnect.com/content/ista/sst/2003/00000031/00000002/art00020 